\title{
Innovative development of the economy as the most important factor in ensuring the financial security of the mining region
}

\author{
Natalia Kudrevatykh ${ }^{1,}$, Tatiana Snegireva ${ }^{1}$ and Anastasiya Tselischeva $^{2}$ \\ ${ }^{1}$ Branch of T. F. Gorbachev Kuzbass State Technical University in Prokopievsk, 653039, Kemerovo \\ region, 19a Nogradskaya str., Prokopievsk, Russia \\ ${ }^{2}$ JSC SUEK-Kuzbass, Mine Management Taldinskoye-Zapadnoye, Russia, 652700, Kemerovo \\ region, Prokopievsky district, village Bolshaya Talda
}

\begin{abstract}
The financial security of the region, being one of the main elements, has a significant impact on the economic security of the Kemerovo region, the largest mining region in the country. The task of the study is to assess the real situation in the financial security of the region and justify the need to develop measures to strengthen it. The article assesses the financial security of the Kemerovo region according to its main criteria: revenues and expenditures of the consolidated budgets of the constituent entities of the Russian Federation per capita; the number of operating credit organizations and their branches per 1000 people of the population; the amount of deposits of legal entities and individuals in credit institutions and bank branches; average amount of individuals' deposits on ruble accounts with the Savings Bank of the Russian Federation; the balanced financial result of organizations' activities, etc. In the course of the work, threats to the financial security of the region were identified, which can be solved by conducting innovations. The results of the study can be used to develop a strategy for the development of the region.
\end{abstract}

\section{Introduction}

The problem of economic security worried the minds of many philosophers, economists and politicians, among them Democritus, Aristotle, Plato. The basis of modern views on the security of society in the XX century was laid by the works of V. Pareto and the outstanding Russian scientist A. Bogdanov.

A considerable number of papers have been devoted to economic security in general and to its certain elements [1-14].

The following types of regional security are distinguished as part of the economic security of the region: industrial, socio-economic, financial, environmental, energy, transport, information, food, etc.

\footnotetext{
*Corresponding author: knv.fk@yandex.ru
} 
In spite of the fact that financial security is the basis of the social and economic security of the region, this aspect is not sufficiently studied at present, and a number of issues remain sharply controversial.

Finance plays an important role in the effective functioning of any socio-economic system; therefore the analysis of the financial sphere should be part of the assessment of the overall level of economic security of the territory.

The purpose of the work is to assess the financial security of the mining region and justify the need to develop measures to strengthen it.

To solve the set goal, the following objectives were solved:

1. The assessment of the financial security of the region by the main criteria is given.

2. The main threats to the financial security of the Kemerovo Region have been identified;

3. The need to increase the level of regional innovative potential for the purpose of ensuring financial security as the basis for economic security of the region has been justified.

\section{Materials and methods}

During the research, such scientific methods as: statistical observation, analysis and synthesis, a systematic approach were used.

\section{Results and discussions}

Considering the Kemerovo region from the standpoint of financial security, it should be noted that this region has been and remains single-industry. The basis of financial security is coal, which makes it dependent on the situation on the foreign market. Today, the Kemerovo region accounts for $58.3 \%$ of all coal production in Russia, $72.7 \%$ of all coking coal production, and $100 \%$ for a whole group of highly valuable coking coal grades. Over the years, the coal industry has allowed the region to maintain a high level of socioeconomic well-being. The realities of today dictate the need for the development of new types of industries. The coal industry, despite its leading position, does not allow the region to maintain a high level of financial security. This is confirmed by the results of the evaluation of statistical indicators for a number of recent years.

To assess the financial security of the Kemerovo region, a comprehensive approach based on the application of the system of indicators and comparison with other territories of the Siberian Federal District (SFD) was used. In this approach, it is necessary to analyze financial security through the following assessment: the state of the regional budget (the ratio of revenues and expenditures of the consolidated budgets of the constituent entities of the Russian Federation per capita); the scale of the banking sector in the region and the well-being of credit institutions; effectiveness of the activities of organizations and enterprises operating in the territory of the entities; financial well-being of the population (by comparing data on the amounts of bank deposits and arrears on loans). The indicators characterizing the financial situation in the region are divided into two groups in accordance with their positive or negative impact on the state of the territory's economy.

The first group of the indicators analyzed in this block is presented in Table 1.

In the table: 1 - Revenues of consolidated budgets of subjects of the Russian Federation in per capita terms, thousand rubles; 2 - Expenditures of consolidated budgets of subjects of the Russian Federation in per capita terms, thousand rubles; 3 - Number of operating credit organizations per 1000 people of the population; 4 - Number of operating branches of credit organizations per 1000 people of the population; 5 - The amount of deposits of 
legal entities and individuals in credit institutions and bank branches, million rubles; 6 The average amount of individuals' deposits on ruble accounts in the RF Savings Bank, rubles; 7 - Balanced financial result of organizations, million rubles

Table 1. Indicators characterizing the level of development of the financial sector in the regions of the SFD in 2015 (the first group)

\begin{tabular}{|l|c|c|c|c|c|c|c|}
\hline \multicolumn{1}{|c|}{ Region } & $\mathbf{1}$ & $\mathbf{2}$ & $\mathbf{3}$ & $\mathbf{4}$ & $\mathbf{5}$ & $\mathbf{6}$ & $\mathbf{7}$ \\
\hline Republic of Altai & 79,1 & 82,2 & 9,3 & 28,0 & 7072 & 4254 & -41 \\
\hline Republic of Buryatia & 53,9 & 55,1 & 1,0 & 8,2 & 38509 & 18135 & 30571 \\
\hline Republic of Tyva & 67,2 & 71,1 & 3,2 & 9,5 & 5875 & 3186 & -4949 \\
\hline Republic of Khakassia & 52,8 & 62,2 & 3,7 & 3,7 & 21843 & 10939 & 8597 \\
\hline Altai territory & 40,1 & 41,2 & 2,9 & 5,5 & 117944 & 64590 & 32534 \\
\hline Trans-Baikal territory & 49,0 & 55,1 & 0,0 & 4,6 & 46994 & 29800 & -291 \\
\hline Krasnoyarsky krai & 73,9 & 81,2 & 1,7 & 10,5 & 208090 & 99141 & 318276 \\
\hline Irkutsk region & 53,5 & 57,6 & 2,9 & 7,9 & 183329 & 90356 & 184288 \\
\hline Kemerovo region & 48,6 & 51,9 & 2,2 & 4,0 & 181614 & 88513 & -15324 \\
\hline Novosibirsk region & 47,9 & 52,7 & 2,2 & 21,1 & 301973 & 92103 & 47290 \\
\hline Omsk region & 39,9 & 42,6 & 2,5 & 10,1 & 133121 & 53204 & 27967 \\
\hline Tomsk region & 57,1 & 59,7 & 1,9 & 15,8 & 89665 & 31672 & 88459 \\
\hline
\end{tabular}

Analyzing the data presented in Table 1 it should be noted that in terms of per capita income and budget expenditures the Kemerovo region shows values that are slightly below the average. However, if we correlate data on these indicators for all subjects of the Siberian Federal District, we can note the absence of an explicit direct link between the level of incomes and expenditures of the budget per capita and the overall socio-economic well-being of the territory. Thus, some of the highest values for the level of per capita incomes and expenditures of budgets were recorded for such regions of the Siberian Federal District as the Altai and Tyva republics. When analyzing the level and quality of life of the population of these republics, they show the worst values for the group of analyzed subjects.

According to the results of the assessment of other components of economic security, these republics often appeared in the second half of the list and, on the contrary, many subjects of the Siberian Federal District, assigned to the leaders, are on average or even lower in terms of per capita incomes and expenditures of budgets. Among the latter, there is also the Kemerovo region. This situation, apparently, is explained by the different degree of effectiveness of the formation and expenditure of financial resources of the analyzed territories.

Starting with the analysis of indicators characterizing the state of the banking sector of the regional economy, first of all, we note that according to the number of operating credit organizations and their branches, reduced to the population, the Kemerovo region is below the average recorded by the district values. And although the situation is somewhat distorted by the value of the Republic of Altai (which is more determined by the population size, rather than by the number of operating credit institutions) by the first of the mentioned indicators, one can note that even the exclusion of the named subject from the analysis does not significantly change the situation.

However, drawing attention to the following indicator of the analyzed group (the amount of deposits of legal entities and individuals in credit institutions and bank branches), it is evident that for this indicator the Kemerovo region exceeds the average by the county, behind Novosibirsk, Irkutsk region and Krasnoyarsk region. 
This ratio of indicators in general is typical for Kuzbass and reflects its specifics, since it is associated with a larger scale of organizations operating in the region than the average for the district.

According to the average size of the deposit of individuals on ruble accounts with Sberbank of Russia, Kuzbass exceeds the average steady-state value by almost $82 \%$. On the one hand, this confirms the previous conclusion, on the other hand, it allows us to speak about a sufficiently high level of financial well-being of the population of the region in comparison with other territories of the Siberian Federal District.

According to the last indicator of the first group - the balanced financial result of organizations - the Kemerovo region is below the average. Analyzing this indicator in absolute terms, we note that the balanced financial result of the organizations of Kuzbass was negative, which affected the location of our region among other regions. A negative financial result was recorded in a number of other regions, including the Republic of Altai, the Republic of Tyva and the Trans-Baikal Territory. However, the largest negative balance was observed on the basis of the performance of organizations of the Kemerovo region.

Indicators of the second group, characterizing the degree of severity of negative trends in the financial sector of the region are presented in Table 2.

The data of Table 2 allow us to note that the severity of negative trends in the financial sector of the Kemerovo region is at a fairly high level, not one indicator falls below the average recorded by the Siberian Federal District values. According to the last two indicators of this group of indicators, the significance of the Kemerovo region can be conditionally recognized as overestimated.

Table 2. Indicators characterizing the level of development of the financial sector in the regions of the SFD in 2015 (the second group)

\begin{tabular}{|l|c|c|c|c|c|}
\hline \multicolumn{1}{|c|}{ Region } & $\begin{array}{c}\text { Debt on loans in } \\
\text { rubles provided } \\
\text { by credit } \\
\text { institutions to } \\
\text { legal entities } \\
\text { (including IE), } \\
\text { million rubles }\end{array}$ & $\begin{array}{c}\text { Debts on loans } \\
\text { in rubles } \\
\text { provided by } \\
\text { credit } \\
\text { institutions to } \\
\text { individuals, } \\
\text { million rubles }\end{array}$ & $\begin{array}{c}\text { Specific } \\
\text { weight of } \\
\text { unprofitable } \\
\text { organizations, } \\
\text { \% }\end{array}$ & $\begin{array}{c}\text { Overdue } \\
\text { accounts } \\
\text { payable of } \\
\text { organization } \\
\text { s, million } \\
\text { rubles }\end{array}$ & $\begin{array}{c}\text { Overdue } \\
\text { accounts } \\
\text { receivables of } \\
\text { organizations, } \\
\text { million rubles }\end{array}$ \\
\hline $\begin{array}{l}\text { Republic of } \\
\text { Altai }\end{array}$ & 12750 & 13956 & 38,8 & 277 & 210 \\
\hline $\begin{array}{l}\text { Republic of } \\
\text { Buryatia }\end{array}$ & 62513 & 91342 & 33,9 & 7952 & 3823 \\
\hline $\begin{array}{l}\text { Republic of } \\
\text { Tyva }\end{array}$ & 3634 & 21419 & 48,9 & 4704 & 1710 \\
\hline $\begin{array}{l}\text { Republic of } \\
\text { Khakassia }\end{array}$ & 15577 & 35004 & 38,4 & 4998 & 3486 \\
\hline Altai territory & 130307 & 155099 & 29,3 & 4834 & 3683 \\
\hline $\begin{array}{l}\text { Trans-Baikal } \\
\text { territory }\end{array}$ & 20864 & 90368 & 41,5 & 8325 & 5853 \\
\hline $\begin{array}{l}\text { Krasnoyarsky } \\
\text { krai }\end{array}$ & 382927 & 290587 & 29,3 & 30317 & 91137 \\
\hline Irkutsk region & 179628 & 236203 & 27,9 & 18869 & 15031 \\
\hline $\begin{array}{l}\text { Kemerovo } \\
\text { region }\end{array}$ & 231636 & 209274 & 36,7 & 127675 & 81597 \\
\hline $\begin{array}{l}\text { Novosibirsk } \\
\text { region }\end{array}$ & 248911 & 248186 & 28 & 7281 & 4630 \\
\hline Omsk region & 137361 & 143160 & 20,9 & 5797 & 3897 \\
\hline Tomsk region & 75200 & 91053 & 28,6 & 16794 & 10082 \\
\hline
\end{tabular}


This is due to the existence of a regularity connecting the size and economic power of the region with the amounts of debts of legal entities and individuals to credit institutions. In addition, the first of the analyzed indicators is calculated based on the location of the borrower, which also somewhat distorts the picture, characterizing the financial well-being of business entities rather than the banking sector of the region. However, on the other hand, the voiced dependence cannot be considered absolute and not always a larger number of loans entails the appearance of large amounts of debt. And the business and banking sector of the region are so strongly connected with each other that, in our opinion, the indicator in question is still quite informative from the point of view of analyzing the financial sphere of the territory. In this regard, the current situation with the amounts of arrears on loans should be recognized as potentially dangerous from the point of view of preserving the economic security of the Kemerovo region.

The spread of regions of the Siberian Federal District in terms of the proportion of lossmaking organizations is low - there are no obvious leaders and outsiders, and Kuzbass is located approximately in the middle of the list of analyzed territories. However, considering that about a third of the enterprises of the Kemerovo Region are unprofitable, such a situation can hardly be considered successful, although this corresponds to the values of other regions taken for consideration.

Turning to the last indicators of this group, characterizing the amounts of overdue receivables and payables, we note that they are also not translated into relative values (as well as the first two indicators of this group). Therefore, for a more reliable analysis, we give the values of the shares of accounts receivable and payable in the total amount of debt (Table 3).

Table 3. Indicators of payables and receivables on subjects of the Siberian Federal District in 2015, \%

\begin{tabular}{|l|c|c|}
\hline \multicolumn{1}{|c|}{ Region } & $\begin{array}{c}\text { Share of overdue accounts } \\
\text { payable as a percentage of } \\
\text { total debt }\end{array}$ & $\begin{array}{c}\text { Share of overdue accounts } \\
\text { receivable as a percentage of } \\
\text { total debt }\end{array}$ \\
\hline Republic of Altai & 8,4 & 5,7 \\
\hline Republic of Buryatia & 19,1 & 6,7 \\
\hline Republic of Tyva & 52,6 & 26,6 \\
\hline Republic of Khakassia & 13,2 & 6,9 \\
\hline Altai territory & 4,5 & 3,8 \\
\hline Trans-Baikal territory & 17,1 & 11,5 \\
\hline Krasnoyarsky krai & 6,5 & 17,8 \\
\hline Irkutsk region & 8,5 & 4,3 \\
\hline Kemerovo region & 26,0 & 16,6 \\
\hline Novosibirsk region & 1,9 & 1,8 \\
\hline Omsk region & 3,8 & 3,2 \\
\hline Tomsk region & 9,0 & 6,1 \\
\hline
\end{tabular}

Analyzing the data in aggregate, it can be concluded that the high place corresponding to the Kemerovo region in terms of overdue accounts receivable and accounts payable is due not only to the more intensive implementation of entrepreneurial activities. Thus, Kuzbass shows one of the worst values across the entire Siberian Federal District (26.0\%) (the lowest is $1.9 \%$ (Novosibirsk Oblast), and the average is $14.2 \%$ ), according to the share of overdue payables. According to the share of overdue accounts receivable, the situation cannot be called good either - $16.6 \%$ with the least - $1.8 \%$ (Novosibirsk region), the average $-9.3 \%$. Separately, it should be noted that in regions that constitute a serious 
competition to the Kemerovo region based on the analysis of other blocks of economic security, there are markedly more favorable values of the indicators in question, which make their competitive status stronger, weakening the position of Kuzbass.

\section{Conclusion}

Summarizing the above, it can be noted that the problem of financial security for the Kemerovo region remains extremely topical. The most serious threats are:

1) low budget revenues and expenditures per capita;

2) a small number of operating credit institutions and their branches per 1000 people;

3) a negative net financial result of the regional organizations;

4) a high amount of debt on loans in rubles provided by credit institutions to legal entities and individuals;

5) more than $36 \%$ of regional organizations are unprofitable;

6) high amount of overdue accounts receivable and accounts payable.

The foregoing allows us to conclude that financial security, to date, requires considerable attention and the development of a set of measures aimed at stabilizing it, which will allow it to become one of the main factors for the sustainable development of the Kemerovo region, and this will positively affect the economic security as a whole. This can be achieved by raising the level of regional innovation capacity.

\section{References}

1. Bussire M., Imbs J., Kollmann R., Rancire R., American Economic Journal: Macroeconomics, 5, 75 (2013)

2. Capone R., El Bilali H., Debs P. et al., Journal of Food Security, 2, 13 (2014)

3. Capone R., El Bilali H., Debs P. et al., Journal of Food Security, 2, 1 (2014)

4. Echterling F., Eierle B., Ketterer S., Int. Review of Financial Analysis, 42, 235 (2015)

5. Glover S.M., Prawitt D.F., Messier W.F., Auditing \& Assurance Services: A systematic approach (McGraw-Hill, 2014)

6. Galbraith, J.K. Economics and the Public Purpose (Boston, Houghton Mifflin Company, 1973)

7. Karen, D.E., Journal of Economic Perspectives, 23, 49 (2009)

8. Kevin M.M., Topel R.H., American Economic Review, 103, 508 (2013)

9. Kormishkina L.A., Kormishkin E.D., Semenova N.N., Koloskov D.A. Mediterranean Journal of Social Sciences, 6, 163 (2015)

10. Kudrevatykh N., Sheveleva O. Coal in the 21st Century: Mining, Processing and Safety, 120 (2016)

11. Perroux, F.L., L'Economie du XX siècle (Presses Universitaires Grenoble, 1961)

12. Pottier, P., Revue Economique, 14, 63 (1961)

13. Sustainable Economic Development. Resources, Environment and Institutions (Massachusetts: Academic Press, 2015)

14. Yu.A. Fridman, G.N. Rechko, A.G. Pimonov, Regional Res. of Russia, 2, 206 (2012) 